that of "sitting up"-an accomplishment which he had great difficulty in acquiring. This was not owing to any stupidity on his part, for when he had once passed over this pons asinorum of dog-performances, he proved to be a vely clever animal, and learnt many other tricks with great ease. He appears, however, never to have forgotten the pains which were taken to teach him his first trick, and to have judged therefrom that there is great merit in sitting up. Not only does he rely upon this as a last re. source to move me to take him out, or not to whip him, but he judges that it must soften even the heart of an india-rubber ball. Sometimes when annoyed at his playing with this, his favourite toy, I have placed it on a chimney-piece, and turned my attention elsewhere. On looking round again I have seen my dog sitting up to the india-rubber ball, evidently hoping that it would jump down and play with him again. Perhaps he looks upon this ball as "animated by a living essence" (ivide Chap. ii. of Darwin's "Descent of Man").

My dog is now the father of a family, and one of his daughters, who has never seen her father, is in the constant habit of sitting up, although she has never been taught to do so, and has not seen others sit up. She is especially given to this performance when any other dog is being scolded. Whether this is an instance of helping a fellow animal, of which Mr. Darwin gives such curious examples, or whether the dog simply hopes to avert the passing storm from her own head, the fact appears to me patent, that this dog has inherited the impression that sitting up has some special virtue for turning away wrath.

Alexandra Hotel, Harrogate, July 27

I. HURT

\section{RECENT OBSERVATIONS IN THE BERMUDAS}

A $S$ my late visit to these islands has placed me in possession of facts relating to their original aspect of a somewhat conclusive nature, I deem it advisable to communicate such in a brief form, instead of awaiting the time requisite for the preparation of a more elaborate paper on the subject.

On previous occasions I have always regretted my inability, from lack of time, to look more closely into their geological character in the hope of discovering some satisfactory clue to their primitive condition. I was aware that in different parts of the islands road cuttings and well borings had revealed layers of red earth at certain depths below the surface, the consistence of which was similar to that now forming the present surface soil, and it did not require much force of imagination, after personal inspection, to conceive that such layers of red earth were first formed by the decomposition of vegetable matter which grew upon former surfaces, and became covered to their respective depths by accumulated masses of drift sand, which from natural causes hardened into more or less compact sandstone. But these different layers were but a few feet beneath the surface, and so, although interesting as throwing light upon the gradua! elevation of the land by drift material forming over them, yet they afforded no evidence of a contrary nature-viz., the submergence of the Bermuda group. Indeed, I have always been led to suppose from appearances that the whole group was the result of an upheaval of the ocean bed slightly above the water level, and a gradual elevation afterwards by means of drift matter aided by the consolidating agency of reef-building zoophytes encircling the whole with a barrier reef, and by isolated patches gradually filling up the space within. The investigations, however, which I have recently been able to make, tend I think to prove that the barrier reef encircling the islands which has hitherto been considered an atoll is merely the remnant of the more compact calcareous rock which formed the shore of a much more extensive island group than that now existing.

My views in this respect are borne out by the following facts :-The barrier reef, as far as I have inspected it, is merely ordinary calcareous rock coated with serpulæ, nullipores, \&c., the reef builders only working in the sheltered waters between the reef and the shore in three to eight fathoms. About two years ago submarine blastings were carried on at the entrance of Hamilton Harbour, and at a depth of over six fathoms a cavern was broken into which contained stalactites and red earth. Again, within the last few months, I have, through the kindness of his Excellency Major-General Lefroy, C.B., F.R.S., the present Governor, been placed in possession of still more satisfactory information. During the past two years extensive submarine blastings have taken place inside an artificial harbour, situate at the western extremity of the islands, for the purpose of forming a bed of sufficient depth for the reception of the "Great Bermuda Dock," which attracted so much attention off Woolwich when launched some three or four years ago. The excavations extended to a depth of fiftytwo feet below low water mark. At forty-six feet occurred a layer of red earth two feet in thickness, containing remains of cedar trees, which layer rested upon a bed of compact calcareous sandstone. Here we have the first satisfactory evidence of the submergence of an extensive deposit of soil once upon the surface, and that to the depth of forty-eight feet below the present low water level, which consequently grants an equal elevation above it in former times. Now, on carefully surveying the Bermuda chart, we find that an elevation of forty-eight feet will bring the whole space which intervenes between the present land and the barrier reef, now covered with water, above the water level. This attained, what more is required to prove the former extent of the island group before the present submergence to the present barrier reef? But having clearly ascertained beyond doubt that the Bermudas were once forty-eight feet higher than at present, will any one be bold enough to deny them a greater elevation? I have reason to believe that they once extended in a south-westerly direction-not only out to the reef, but to a greater distance. There are some rocky ledges about twenty to twenty-five miles from land in that direction, known as "The Flatts," lying in about thirtyfive to forty fathoms water; and, singularly enough, in the very oldest maps of the Atlantic, copies of which I have consulted in the British Museum, "The False Bermudas" are put down about this position. Is it unreasonable to suppose that a low lying group of islets did actually exist here in former times? Again, in Smith's "History of Virginia," which gives an excellent account of the islands in the early part of the seventeenth century, it is stated among other notes upon their natural history that flocks of crows, no doubt the same species (Corvus Americanus) which now inhabits them, were in the hapit every evening of winging their flight from the main island towards the north. This observation, which from its simplicity I should the more readily believe to be a true statement, would clearly prove the existence of land in that direction at no great distance; for the habit of this bird to leave its roosting place for distant feeding grounds during the day, to return at random, is one of its well-known characteristics.

Taking these matters into consideration, I see everything to support the supposition that the Bermudas once presented a much more extensive aspect than they do at present, and certain additional evidences which I hope to bring forward shortly in a collected form will, 1 conceive, tend to confirm my impression that the restricted terraqueous area lying within the limits of the outer barrier reef is merely the summit of one of a range of islands wbich extended in somewhat semicircular form for a distance of seventy or eighty miles, and which have suffered submergence to a depth only to be correctly ascertained by borings, which might be successfully accomplished under the auspices of the Imperial Government at a trifling expense. J. MatTHEW JONES 